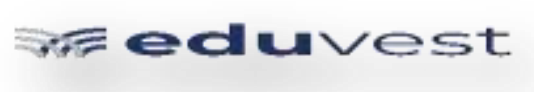

Eduvest - Journal of Universal Studies

Volume 2 Number 1, January 2022

p- ISSN 2775-3735 e-ISSN 2775-3727

\title{
PILLARS OF PLURALISTIC EDUCATION FOR CHRISTIAN EDUCATION IN THE CONTEXT OF MULTICULTURAL INDONESIA
}

\author{
I Made Suardana 1,I I Putu Ayub Darmawan ${ }^{2}$
}

Toraja State Christian College ${ }^{1}$, Simpson College of Theology ${ }^{2}$

Email: madeintoraja@gmail.com ${ }^{1}$, putuayub.simpson@gmail.com ${ }^{2}$

\begin{tabular}{|c|c|}
\hline ARTICLE INFO & ABSTRACT \\
\hline $\begin{array}{l}\text { Received: } \\
\text { December, 26 } \\
2021 \\
\text { Revised: } \\
\text { January, 17th } \\
2022 \\
\text { Approved: } \\
\text { January, 18 } \\
2022\end{array}$ & $\begin{array}{l}\text { Indonesia is a nation with a plurality of people. This is an } \\
\text { advantage that can produce strength as well as a problem } \\
\text { if it is not interpreted properly. This article presents a } \\
\text { literature study on the pillars of pluralism education for } \\
\text { Christian education. According to the author there are three } \\
\text { pillars of pluralism education for Christian education in the } \\
\text { multicultural context of Indonesia, namely the pillar of the } \\
\text { Authority that emphasizes education in bringing wealth of } \\
\text { faith, the pillar of Identity, namely education as a } \\
\text { realization of humanity, and the pillar of reality which } \\
\text { emphasizes that education is the nature of freedom. }\end{array}$ \\
\hline KEYWORDS & Pluralism, Multiculturalism, Christian Education \\
\hline (c) (†) (P) & $\begin{array}{l}\text { This work is licensed under a Creative Con } \\
\text { Attribution-ShareAlike } 4.0 \text { International }\end{array}$ \\
\hline
\end{tabular}

\section{INTRODUCTION}

The Indonesian nation is a multicultural, multi-ethnic, multi-religious nation, a pluralistic nation. This plurality is a wealth for the Indonesian people. However, if this wealth is not managed and handled properly it can cause various problems in social life (Noti \& Darmawan, 2016). (Suparlan, 2002)_ reveals that Indonesia has a common culture, but in this general culture there are small cultures that exist in smaller communities. The smaller society forms a larger society, as well as the smaller culture forms a larger culture. Indonesia is a multicultural society that is characterized by a pluralistic society and forms a culture for Indonesia. The motto of Bhineka Tunggal Ika is a manifestation that Indonesia is a multicultural nation. The motto gives the structure of Indonesian society both nationally and locally.

\begin{tabular}{cl}
\hline & I Made Suardana, I Putu Ayub Darmawan. (2022). Pillars of \\
& Pluralistic Education for Christian Education in the Context of \\
How to cite: & Multicultural Indonesia. Journal Eduvest. Vol 2 (1): 64- 74 \\
E-ISSN: & 2775-3727 \\
Published by: & https://greenpublisher.id/
\end{tabular}


As a large nation, the Indonesian nation is identical with its diversity and this diversity is generally an important aspect of the life of the Indonesian people and natio (SUSANTO, 2016) (Cardoso et al., 2019; Llorca et al., 2019). This multicultural dimension, of course, does not only include religious differences, but also leads to a complete Indonesian national identity, including cultural, ethnic/ethnic characteristics, as well as lifestyle/way of life. Antone (2010) understands that the term multicultural or pluralism has also been used for gender, social status, sexual orientation, and other differences that of course cross racial and ethnic lines. On the other hand, society's worldview is also greatly influenced and actively participates in influencing the existing pluralism (Verkuyl, 1989) (Aaij et al., 2010). In this regard, Wright (1992) places multicultural reality at the level of one's worldview. Nash directs the understanding of worldview to one's worldview, namely as a circle that complements each other on a greater or lesser level. But on the other hand, a person's worldview has the potential to become a conflict, namely when two people meet whose worldviews fail to complement each other completely. Thus, it can be emphasized that plurality concerns one's worldview which always influences the birth of decisions that are theoretical (epistemology), ethical (ethics), realistic (metaphysical), and dogmatic (theology) regarding one's existing diversity/multiculturality (Nash, 2013). Reflecting on the multicultural context of Indonesia, the existence of each ethnic group with all its entities forms the perspective, behavior and portrait of the plurality of a multicultural society.

In realizing the life of the nation and state, and participating wisely and actively in building the nation of church members, including through Christian education, it is necessary to play a role in making it happen (Riniwati, 2016). To manage education in the plurality of the Indonesian nation, it is necessary to have an in-depth understanding of the pillars of pluralism education in Christian education. Because according to Tety and Wiraatmajda (2017) practical action requires a philosophical framework, that's why to provide direction for pluralistic education, it is necessary to first build a philosophical framework. Lie (2019) revealed that designing a praxis in Christian education is not easy, the design must start with a philosophical framework that underlies the praxis. According to Nuhamara, it was the same as what Groome did. To formulate his educational goals, Groome begins by finding or building on his philosophical foundation (Lucena et al., 2011) (Nuhamara, 2018). Meanwhile, in the idea of Panggabean (2018), he put forward a theological-praxis approach in the foundation of Christian education. The idea of Panggabean (2018) shows that the Bible is the theological foundation which then provides the foundation for other parts of the foundations and pillars of education. In this case, according to the author, the pillar of pluralism must still be built on the basis of biblical values which then provide a philosophical framework. This means that in order to strengthen the praxis of pluralism education, the pillars of pluralism education which are part of the philosophical foundation need to be put forward.

From this background, this paper examines the pillars of pluralism education which will become the philosophical foundation of multicultural education. The formulation of the problem in this research is what are the pillars of pluralism in Christian education? The purpose of this study is to present the pillars of pluralism in Christian education.

\section{RESEARCH METHOD}

In this research, the writer uses a literature study approach using descriptive analysis method. The analysis process is carried out in several stages, namely First, the process of collecting library data, then reading and recording important information related to pluralism. Some of the literature sources that the author uses are Rintis (2010) in his book 
Theology for All, Schumann (2011) in Religions of Violence and Peace, Groome (2011) in Christian Religious Education, Tilaar (2003) in Power and education: an overview from the perspective of cultural studies. Other sources from books and journals that are directly related to the issue of pluralism and education in the Indonesian context are used as supporting sources in this paper; Second, writing elaborates on various ideas in the selected literature sources and interprets the library sources used (Soejono \& Abdurrahman, 1999, p. 25); Third, the writer then presents the data in a thematic descriptive manner in accordance with the previous process. From the analysis of various literature sources, the author conceptually builds three pillars of pluralism, namely authority, identity, and reality.

\section{RESULT AND DISCUSSION}

\section{Pillars of Authority: Education Brings Wealth of Faith}

Tillich says it's hard to talk about God today, because people immediately ask "does God exist?" According to Tillich (1959) this means that the symbol of God is no longer working. Tillich (1959) reveals that instead of pointing beyond himself to an ineffable reality, the humanly conceived edifice of ideas called God has become the end of the story. In the early modern period, the idea of God was reduced to a scientific hypothesis and God to the ultimate explanation of the universe. Instead of symbolizing the indescribable, God is actually reduced to mere devas, lower gods who are members of the cosmos with specific functions and locations. When that happens, it is only a matter of time before atheism becomes a viable proposition, as scientists quickly find explanations for alternative hypotheses that make "God" redundant. This would not be a disaster if the churches had not relied on scientific evidence. Other paths to knowledge have been belittled in the modern world, and scientific rationality is now considered the only acceptable path to truth. People have become accustomed to thinking of God as a clear, distinct, and self-evident idea (Armstrong, 2011).

It is appropriate now that the dynamics of faith are re-aligned with the purity of life in a transcendent-immanent relationship. Premodern religion deliberately humanizes the sacred, Brahman is not a distant reality, but is identical with the atman of every creature. Confucius refused to define ren, because it was incomprehensible to those who had not yet attained it, but the everyday meaning of ren in Confucius' time was human. When Buddhists contemplate the serene, serene, and selfless nature of the Buddha, they see him as the incomprehensible Avatar of Nirvana without him; this is how Nirvana appears in human form, and that if they practice the Buddha's method, they too can attain it. Christians have a similar experience when imitating Christ, bringing them closer to theosis (Armstrong, 2011).

Implementing a transcendent-immanent existence in Christian education answers the reality of its plurality. The text of Luke 11:34 is a biblical text which means that faith is the reality of seeing with the eyes of faith as the whole act of faith. In Luke 11:34 it is written that "Your eye is the lamp of your body; if your eye is good, your whole body will be full of light; but if your eye is evil, your body is darkened." Thus, each person's faith identity has a basis for his encounter in a multicultural society. The identity of his 
faith becomes a lamp for his actions. In the Indonesian context, when the encounter touches various cultural dimensions, the form of strong faith is a concern that touches the deepest humanity that is revealed to the way of life it displays. When the encounter involves religious plurality, everyone's faith will underlie the encounter, so that the approach is no longer on religious fanaticism, or rejection of the presence of other religions, but has moved towards working together utilizing the strength of a solid faith.

The richness of a Christian's faith in Jesus will enable him to produce great works that are ready to share and support others, whoever they are, to build their lives. In this case, Lumintang (2009) understands it as an effort to bridge religion and humanity. When that doesn't happen, religious fanaticism that includes claims of absoluteness, belittling claims so that the defense of religion becomes a spectacle of vile, cruel, and full of violence. Cruelty and violence are a picture of the fragility of one's religious understanding and experience (Marlina, Saleh, \& Lumintang, 2009). Religious understanding and experience is the reality of the power of faith that fosters high responsibility and solidarity that underlies religious dynamics that are born and grow in a plurality container.

Rintis (2010), interprets that the richness and depth of one's theology is the basis for the development of one's attitude to life in viewing and separating issues that can be negotiated or tolerated from issues that need to be fought with all their might. At this level the author understands that the strength of faith is identical to the depth or richness of one's theology. Faith not only confirms belief or trust in God and His works, but is also an attitude of life that confirms that God's great love has touched the life of a person and everyone through the faith that is turned on by someone who believes. In this case, the writer understands what Rintis means that theology is action (Rintis, 2010). One's faith has a close relationship with the knowledge of God, which is interpreted as the theology. Thus faith is born from the wealth of one's theology and becomes an inseparable part of one's theology. On the same level theology and faith mean to act, to do, nothing less. Both theology is also faith, and faith is also theology because both address everyone, even God through the language of action. Rintis (2010) understands that theology is not only a theoretical study that needs to be put into practice, so it seems that there is a separation between theology and practice, but a practice that discusses theology in actions that reveal the greatness of God that touches everyone's life. At this level the author positions it in the study of a person's faith that underlies his encounter with pluralism/diversity, so that the language of faith that is present in the encounter with pluralism is not the language of narrow religious fanaticism, which shouts blasphemy, rejection and even anarchism, even though they have to deal with issues. which cannot be tolerated (Rintis, 2010). Lumintang (2009), interprets that faith and the response of believers are an absolute element that cannot be ignored in the theological endeavor. However, in Naftalino's view and the author also emphasizes that labeling Christian theologians as "grey theologians" who are open and dare to dialogue with other religions is an attitude that denies pluralism. Naftallino (2010) explains that Wilfred Cantwell Smith, a professor of comparative religion, also emphasized that avoiding associating with other communities in the necessity of pluralism is an impossibility or a kind of insane arrogance. For example, James Edward Lesslie Newbigin is really able to interpret that pluralism is not easy to enter into real life and oppose the waves of contemporary thoughts and feelings that are blowing towards the acceptance of religious pluralism, and away from the belief in the absolute sovereignty of Jesus Christ. However, reading the integrity of Newbigin's theology, it can be seen that in fact he intelligently and biblically holds the uniqueness of Jesus in the midst of the plurality of religious concepts. Newbigin emphasized that the world in which the early Christians preached the Gospel was a world 
full of religious pluralism and even pluralism had become the face of life in the days of the ancient people of God. Where the people of Israel are prohibited from associating with all forms of religion of the surrounding nations. Associating in terms of building equality in their beliefs (Kusni, 2020)

The strength of faith is very important in building the dynamics of a meaningful encounter for the multicultural Indonesian people, especially presenting Christian religious education in it. The author understands that the encounter of a Roman officer with Jesus who appreciates him is the soul of Jesus' multiculturalism (Luke 7:9). In connection with the text of Luke 7:1-10, Leks (2003) notes that, the story of the encounter that occurred between the Roman centurion and Jesus, is not merely about the healing power of Jesus, which Jesus had done many times, but about faith that should be imitated. According to Larson (1983), the story also not only emphasizes that a Gentile has faith, but also emphasizes a person who truly has mature faith (He has a remarkably mature faith). In this case Jesus said, "I have never seen such great faith" (7:9). Obviously this is an extraordinary multicultural attitude or soul of Jesus. Anyone can, is worthy, and can be accepted in the fullness of Jesus' love, and that is only because of true faith in Jesus. Thus the principle of faith is actually neutral, not insulated by culture, customs, gender, social status, even if referring to the Indonesian context where there is a diversity of religious beliefs, of course what the author means here is that even if it is clearly visible to the head of the army, faith is actually, beyond that limit. But Luke did not mention about the belief, which is clearly not a Jew, so it is clear that he did not practice the beliefs of the Jews.

Understanding this in an effort to respond to the encounter of Christian faith in the world of Christian education in a multicultural context in Indonesia, it is appropriate to take a faith approach that truly looks at the greatness of Jesus' love that every person in his existence, even in the integrity of his faith, the presence and love of Jesus does not exist. can be limited. Faith in Jesus Christ is not limited by the existence of ethnicity, culture, religion and other diversity. Thus, relationships with anyone is an area where faith in Jesus can be developed, so that the presence of Jesus answers their needs and saves their lives. Leks (2003) notes that the request of the commander/commander of the Roman army deserved to be granted, not because he did good to the Israelites, but because he believed that God in Jesus Christ conquered death. The faith of this commander/troop head is unexpected and very different from those who think they believe but do not actually believe (Leks, 2003). The principle of faith in the Roman army chief can be understood as an affirmation of the presence of Christian education in the midst of a multicultural context by exercising a true firmness of faith in Jesus. If translated into the dynamics of faith in Indonesia, it means that it cannot be separated from working a life of sharing. Groome (2011) notes that, when Christian faith is understood as an activity of believing, entrusting, and taking action in response to the Kingdom of God, it is clear that such a way of faith, by the grace of God, is an expression of a complete human being, namely his identity. However, if self-identity is formed by interaction with the collectivity, then to become a Christian it is necessary to have social interaction with the Christian faith community that is able to form such a way of faith. All Christian education efforts will bear no fruit unless all educational efforts take place within the Christian faith community, and educational activities for the living Christian faith will be more successful if more faith fills that community (Groome, 2011). In line with what Groome explained, Wolterstorff (2004) notes that the basic belief that Christians must have in facing the reality of pluralism is to make their whole life the implementation of their faith in God as revealed in Christ. The encounter of Christian education in the context of pluralism cannot leave the maturity of the building of faith in 
relation to each person (community), which builds the strength of true faith. Communities in which the pattern of life of faith is manifested will form a community with the same goal of faith.

Palmer (2009) uses the metaphor of friendship to emphasize the meaning of education. In connection with the metaphor of friendship built by Palmer, the learning process of Christian education in the integrity of pluralism must be developed in the same direction. First, the multicultural context is not a challenge that requires the faith approach to be interpreted as a barrier. With strong faith, every encounter with diversity is always interpreted as an encounter that complements, strengthens, and increases the growth of faith. Second, sharing the quality of faith means sharing an act of faith. Love, friendship, concern for the needy and uphold the dignity of life as a human being who glorifies the greatness and glory of God. Third, confronting Christian faith with efforts to educate in pluralism, means the basis of the strength of faith as a power to build friendship values. The concept of friendship that is built in the educational process is to respect students in their integrity as learning subjects.

According to Brownlee (2004), according to Jesus, neighbors in life are anyone who needs attention, everyone. When the scribes asked, "Who is your neighbor?" Jesus tells of a Samaritan who saved a Jew who was about to die, even though the Jew and the Samaritan were estranged from each other. Song (2008) emphasizes "in Christ there is no stranger." The concept of Song refers to Jesus' attitude when dealing with the Roman centurion at Capernaum. Jesus broke the cultural deadlock referring to the centrism of the faith and the centrism of the Jewish religious community. According to Jesus faith must go far beyond religious and national centrism, even faith does not have to be divided into liturgical language or the theological language of Judaism but in a proper military language "I am not worthy to receive the Lord into my house", he told Jesus (Song, 2008) ). Then his Roman military language turned into his confession of faith: "Just say a word and my servant will be healed. For I myself am a subordinate and under me are soldiers. If I say to one of the soldiers: "Go" he goes and to another" "Come" he comes or to my servant: "do this" and he does it" (Luke 7:7-8). What does all this mean? Can faith in Jesus transcend cultural, ethnic, religious and other boundaries? Jesus answered the centurion, "I tell you, I have never seen such great faith, not even among the Israelites" (7:9). Song (2008) asserts that Jesus' firm statement is not a matter of comparing faiths, but presenting a practice of faith that touches God's heart - a faith that can exist outside the realm of Jewish religion. Referring to the reality of pluralism in Christian education, what Palmer (2009) notes can be a warning for Christian educators.

If I forget the plurality within me and also forget about my long journey to become who I am, then my expectations of my students become excessive and unreal. If I could remember the plurality in my soul and the slow pace of self-discovery, I would be able to better deal with the plurality in my students at a pace that was appropriate for their young age. By remembering our teacher, we can remember ourselves, by remembering ourselves, we can remember our students.

Christian education is responsible for solving people's faith problems. Without the intention to judge with the correct model or concept of faith, Christian religious education is carried out with the aim of restoring the focus of faith to a faith that touches the heart of God, a faith centered on Jesus that does not discriminate among others. Walters (2003) interprets that as Jesus asserted "to give is nobler than to receive," because to give means to expand oneself, and to liberate. Giving creates joy in the giver. A generous heart sees a world full of trust, not a cruel world

Palmer (2009) uses the metaphor of friendship to emphasize the meaning of 
education. In connection with the metaphor of friendship built by Palmer, the learning process of Christian education in the integrity of pluralism must be developed in the same direction. First, the multicultural context is not a challenge that requires the faith approach to be interpreted as a barrier. With strong faith, every encounter with diversity is always interpreted as an encounter that complements, strengthens, and increases the growth of faith. Second, sharing the quality of faith means sharing an act of faith. Love, friendship, concern for the needy and uphold the dignity of life as a human being who glorifies the greatness and glory of God. Third, confronting Christian faith with efforts to educate in pluralism, means the basis of the strength of faith as a power to build friendship values. The concept of friendship that is built in the educational process is to respect students in their integrity as learning subjects.

According to Brownlee (2004), according to Jesus, neighbors in life are anyone who needs attention, everyone. When the scribes asked, "Who is your neighbor?" Jesus tells of a Samaritan who saved a Jew who was about to die, even though the Jew and the Samaritan were estranged from each other. Song (2008) emphasizes "in Christ there is no stranger." The concept of Song refers to Jesus' attitude when dealing with the Roman centurion at Capernaum. Jesus broke the cultural deadlock referring to the centrism of the faith and the centrism of the Jewish religious community. According to Jesus faith must go far beyond religious and national centrism, even faith does not have to be divided into liturgical language or the theological language of Judaism but in a proper military language "I am not worthy to receive the Lord into my house", he told Jesus (Song, 2008) ). Then his Roman military language turned into his confession of faith: "Just say a word and my servant will be healed. For I myself am a subordinate and under me are soldiers. If I say to one of the soldiers: "Go" he goes and to another" "Come" he comes or to my servant: "do this" and he does it" (Luke 7:7-8). What does all this mean? Can faith in Jesus transcend cultural, ethnic, religious and other boundaries? Jesus answered the centurion, "I tell you, I have never seen such great faith, not even among the Israelites" (7:9). Song (2008) asserts that Jesus' firm statement is not a matter of comparing faiths, but presenting a practice of faith that touches God's heart - a faith that can exist outside the realm of Jewish religion. Referring to the reality of pluralism in Christian education, what Palmer (2009) notes can be a warning for Christian educators.

If I forget the plurality within me and also forget about my long journey to become who I am, then my expectations of my students become excessive and unreal. If I could remember the plurality in my soul and the slow pace of self-discovery, I would be able to better deal with the plurality in my students at a pace that was appropriate for their young age. By remembering our teacher, we can remember ourselves, by remembering ourselves, we can remember our students.

Christian education is responsible for solving people's faith problems. Without the intention to judge with the correct model or concept of faith, Christian religious education is carried out with the aim of restoring the focus of faith to a faith that touches the heart of God, a faith centered on Jesus that does not discriminate among others. Walters (2003) interprets that as Jesus asserted "to give is nobler than to receive," because to give means to expand oneself, and to liberate. Giving creates joy in the giver. A generous heart sees a world full of trust, not a cruel world

forward into a single unit. Moving in a circular line does not mean that he lives alone, but there he is closely related to his fellow relatives in his room, who cross the same line of life. Adiprasetya (2020) calls this a labyrinth of life. The dimensions of his life include both his present life which is secular or current in nature, as well as those that cross the boundaries of the present which are usually called religious or transcendent. The religious dimension and the secular dimension are closely related and cannot be 
separated, let alone contradicted (Schumann, 2011). Thus, the nature of education is also a dimension/space/region that cannot be contrasted between religious and secular dimensions.

Today's humanitarian cases are generally referred to as human rights violations that occur in almost all levels of society in Indonesia. These cases touch on the circular dimension that places the present as the whole of the past and the realization of the future as described by Schumann. The question is "Is the evidence of humane behavior precisely because of the presence of inhumanity?" So that the good is certain because of the bad. Likewise, poverty does not stand alone, there is prosperity and even luxury that distinguishes it. When the world is a whole of cause and effect, then any reality should be built in the beauty of harmony. Harmony is celebrating every existence in the frame of wholeness, although the dynamics of wholeness do not always mean the same thing. Diversity is wholeness, it is impossible to separate diversity from the essence of wholeness, because otherwise there is no real diversity. Freire (1998) asserts that it is the same with education that one goal of education is to bring out the same elements of humanity in humans. The elements are basically no different even though the place and time are different. So the assumption that humans must be educated to live in a certain place or time, adapt humans to a certain environment, is a foreign idea and is not in accordance with the conception of true education. It is the elements of humanity that constitute the integrity of education, regardless of whenever and wherever the elements of humanity which are the nature of education will remain the same. In this case, Freire explained that according to Aristotle, reason and thought were the goals of education. Reason and thought are the essential elements of humanity, so that any education that does not support it is a pseudo-education which emphasizes the mistake of determining the direction of education (Freire, 1998).

\section{Pillar of Reality: Education of the Nature of Freedom}

The world of education is a very significant forum for presenting multiculturality, not just presenting it but as an important pillar in designing the "face" of pluralism in the sublime behavior of life in it. Pluralism must be interpreted as an effort to see diversity as a force that is increasingly enriching and increasing the actualization of education as a whole. Therefore, education for the Indonesian context as much as possible is placed as an educational process that originates from and for life. This emphasizes the meaning that there is an effort to maximize education in contact with the realities of life, or education that is in direct contact with the diverse culture of the Indonesian nation. Of course, such conditions can produce outcomes that are not alienated from themselves and from their world (Tilaar, 2003). In this case, education is called dignified because the degree and dignity of human beings as homo potential continues to be favored (Tilaar, 2003). As a homopotent, humans have been born with potential and talent within themselves, but these potentials and talents do not necessarily develop optimally without being supported by empowerment through the educational process.

Thus, education is essentially as much as possible building education that is humanistic, building alignments with human identity (Driyarkara, 1991). Humanist education can be understood as a model of education that respects humans for the human potentials that already exist in them, namely humans as homo potentials. In this educational model, humans are seen as autonomous subjects, so education must be student-centered. Raharja and Sulo (2005), give the term that it is humans as the target of education. As long as the aim of education is to introduce students to the reality around them and to make them aware of the domestication process that is taking place 


\section{Eduvest - Journal of Universal Studies \\ Volume 2 Number 1, January 2022}

happens to it, then students should no longer be crammed with rote theory but by bringing them to reality itself (Tilaar, 2003). In other words, education must be based on cultural recognition and build people on their culture (Dewantara, 1956; Darmawan and Sujoko, 2019). Humanist education can also be interpreted as humanitarian education, namely as a form of education born from the awareness that humanity is something that has been instilled in humans since they were created, so that humans live like humans (Tauchid et al., 1961; Wahuno, 2017). Humanist Reality etymologically the term humanism comes from the classical Latin word, namely humus which means soil or earth. From this term comes the word homo which means human (earthly creature) and humanus which shows more "earthly" and "humane" nature. Similar terms from the word humilis which means "modesty" and "humility". Humanism shows at the core of the problem, namely humanus or humans themselves. This means that the ways in which humans (humanus) become more human (humanismus) through the parties who are responsible for the formation process (humanista). There are three things that are interrelated, namely humanus, humanismus, humanista. This view gives the meaning that humans shape humanity to be more human in order to become human. To human nature itself who has the freedom to be responsible.

Humanist education (humanity) orientation lies precisely in how a Christian educator builds educational values capable of doing "defense" to students as whole individuals, who cannot be separated from themselves and their world, from culture and their perspective from the way they "read". life and purpose in life. Not to separate between faith and the practice of living a faithful life. Faith must produce practice, or in other words faith must produce the fruit of faith. Carrying out education, especially regarding the identity of humanist education, it is necessary to build the right track that humanist education lies in respecting the uniqueness of students and their supporting factors. Walters (2003) interprets that humans as social beings, many of their most pressing problems revolve around their integration into the society in which they live. The human conscience, according to a sociological approach, all develops from the demands made by society on each individual member, in this case also Tilaar places education as an essential activity in every community life. Education may not occur or be separated from people's lives (Tilaar, 2003; Walters, 2003).

Tilaar (2003) asserts that education is essentially a process to find the identity of a person or a group. Therefore, the correct educational process is one that frees a person from various confines or empowers or becomes aware of the abilities or identity of a person or group (Tilaar, 2003). Therefore, when education is directed to control with the aim of being the 'ownership' of the right to manipulate for profit or power, education as the value of ownership has robbed of the most principle value in education, namely freedom. This is what Tilaar makes sure to happen in the sphere of education that robs freedom, namely the growth of a spirit of duping or taming that kills creativity and turns humans or students into robots who simply accept the transmission of existing cultural values. The educational process has been replaced by a domestication process, the result of which is not liberation but duping (Tilaar, 2003, 2009). Education has denied the existence of humans as homo-potent beings with the integrity of their desires to grow, develop and achieve their independence. This is the focus of Aristotle (384-322 BC) who asserts that it is not possessions, but human desires that must be equalized, and this is impossible unless they have adequate education according to circumstances (Freire, 1998).

The keyword "have an education" is the value of equality which is the nature of freedom. Freedom gives a reality that is useful for life, not a reality that betrays life like 
an uneducated life.

Education is the key to freedom and freedom is an autonomous value in education. Freedom may be similar to a term that is often associated with animals, because animals are associated with being unreasonable and unable to reason. Human freedom is the ability to regulate non-freedom in contrast to animal freedom which is unmanageable freedom. In this case, education becomes important for activities to control non-freedom into freedom, because it is in the frame of freedom that humanity responds to its integrity. It is at this level that democracy becomes clear that the result of democracy is not a product of goods, but a product in the form of free human beings. It is in this case that John Dewey's democratic education becomes clear that democracy is inhabited by humans who always have open possibilities which are referred to as problematic situations who with the ability of their minds develop alternatives for the best solution. As life is the dynamics of the whole process that places humans not only in childhood, but towards maturity to the highest stage, namely independence, education makes humans whole in every process of life. When a man who is able to learn makes the decision to stop learning himself because all his abilities are no longer used, then anything in man can no longer be maintained, truth will not last long, freedom will reach its limit into nothingness. This means that it can be equated that education which is free in nature cannot be different in its meaning with democratic education as a form of integration of the needs of students with their culture which comes from the products of social life and human social activities (students). Therefore, by raising the cultural development aspect of behavior, it also directly considers the social development aspect (Ardichvili, 2010; Ardichvili, Jondle and Kowske, 2010).

\section{CONCLUSION}

From the analysis of various relevant literatures, there are three pillars of pluralism, namely the pillars of authority, the pillars of identity, and the pillars of reality. The Pillar of Authority, namely education presents the wealth of faith. In the life of a multicultural society, imposing a transcendent-immanent existence in Christian education is the answer to the reality of its plurality. The identity of each person's faith is the basis for his encounter in a multicultural society. When the encounter touches the dimension of culture or culture that brings with it various differences between oneself and others, the form of strong faith is a concern that touches the deepest side of humanity that is not revealed to the form or way of life it displays. In a multicultural life, Christian education is responsible for solving people's faith problems, restoring the focus of faith to faith in God, faith centered on Jesus that does not discriminate among others.

The Pillar of Identity is education as a humane realization. Education is not a mere concept, but a principle of usefulness for humanity. Therefore, education is placed in human relations with various interdependent attributes. In the context of Christian education, education is not only an order of theological concepts, but theology that colors human life. In this case, the religious and secular dimensions will always exist and continue to develop and move to embrace and sharpen each other. Religious values do not merely stake everything on mythological fantasy but move towards hermeneutic transformation, but secular values are moved within the framework of human integrity as rational and religious beings, thus giving birth to intelligent, scientifically minded individuals who do not separate science. as a whole spirituality, which does not leave the wealth of faith and considers it a step backwards for the progressivity of science.

The pillar of reality is education which is free in nature. In essence, education is humanistic, building alignments with human identity. In this case, education respects 
humans with their human potential and builds humans in their culture. Because education is essentially a process to find the identity of a person or a group, the correct educational process is one that frees a person from various confines or awareness of the abilities or identity of a person or group. Therefore, education cannot be understood as ownership for the sake of power, because if so, this will kill creativity and make humans or students as robots who simply receive the transmission of existing cultural values.

\section{REFERENCES}

Aaij, R., Beteta, C. Abellan, Adeva, B., Adinolfi, M., Adrover, C., Affolder, A., Agari, M., Ajaltouni, Ziad, Albrecht, J., \& Alessio, F. (2010). Measurement of $\sigma\left(\mathrm{pp} \rightarrow \mathrm{bb}{ }^{-}\right.$ $\mathrm{X})$ at $\mathrm{s}=7 \mathrm{TeV}$ in the forward region. Physics Letters B, 694(3), 209-216.

Armstrong, J. Scott. (2011). Illusions in regression analysis. Available at SSRN 1969740. Cardoso, F., Kyriakides, S., Ohno, S., Penault-Llorca, F., Poortmans, P., Rubio, I. T., Zackrisson, S., \& Senkus, E. (2019). Early breast cancer: ESMO Clinical Practice Guidelines for diagnosis, treatment and follow-up. Annals of Oncology, 30(8), 1194-1220.

Kusni, Markus. (2020). Jiwa Entrepreneurship Pemimpin dalam Penatalayanan Gereja. PNEUMATIKOS: Jurnal Teologi Kependetaan, 10(2), 160-175.

Llorca, Alfredo, Ciceri, Gabriele, Beattie, Robert, Wong, Fong Kuan, Diana, Giovanni, Serafeimidou-Pouliou, Eleni, Fernandez-Otero, Marian, Streicher, Carmen, Arnold, Sebastian J., \& Meyer, Martin. (2019). A stochastic framework of neurogenesis underlies the assembly of neocortical cytoarchitecture. Elife, 8, e51381.

Lucena, M. Isabel, Molokhia, Mariam, Shen, Yufeng, Urban, Thomas J., Aithal, Guruprasad P., Andrade, Raúl J., Day, Christopher P., Ruiz-Cabello, Francisco, Donaldson, Peter T., \& Stephens, Camilla. (2011). Susceptibility to amoxicillinclavulanate-induced liver injury is influenced by multiple HLA class I and II alleles. Gastroenterology, 141(1), 338-347.

Marlina, Lina, Saleh, Amiruddin, \& Lumintang, Richard W. E. (2009). Perbandingan efektivitas media cetak (Folder dan poster-kalender) dan penyajian tanaman zodia terhadap peningkatan pengetahuan masyarakat. Jurnal KMP (Jurnal Komunikasi Pembangunan), 7(2).

Nash, Gary B. (2013). The urban crucible. Harvard University Press.

Noti, Fonita Babang, \& Darmawan, I. Putu Ayub. (2016). Identitas Kristen Dan Peran Pendidikan Agama Kristen Di Tengah Kemajemukan. Seminar Nasional Pendidikan Agama Kristen Dan Call for Papers.

Nuhamara, Daniel. (2018). Pengutamaan Dimensi Karakter Dalam Pendidikan Agama Kristen. Jurnal Jaffray, 16(1), 93-114.

Riniwati, Harsuko. (2016). Manajemen Sumberdaya Manusia: Aktivitas Utama dan Pengembangan SDM. Universitas Brawijaya Press.

Suparlan, Parsudi. (2002). Multikulturalisme. Jurnal Ketahanan Nasional, 7(1), 9-18.

SUSANTO, AGUNG PRASETYA. (2016). GEREJA YANG RELEVAN DAN SIGNIFIKAN.

Verkuyl, Henk J. (1989). Aspectual classes and aspectual composition. Linguistics and Philosophy, 12(1), 39-94. 